\section{Effect of Passive Ultrasonic Irrigation on Enterococcus faecalis from Root Canals: An Ex Vivo Study}

Juliane Maria Guerreiro-Tanomaru', Gisselle Moraima Chávez-Andrade', Norberto Batista de Faria-Júnior ${ }^{1}$, Evandro Watanabe², Mário TanomaruFilho $^{1}$
'Department of Restorative Dentistry, Araraquara Dental School, UNESP - Universidade Estadual Paulista, Araraquara, SP, Brazil ${ }^{2}$ Department of Dentistry, School of Dentistry of Ribeirão Preto, USP - Universidade de São Paulo, Ribeirão Preto, SP, Brazil

Correspondence: Prof. Dr. Mario Tanomaru-Filho, Rua Humaitá, 1680, CP 331, 14801-903 Araraquara, SP, Brasil. Tel: +55-16-3301-6391. e-mail: tanomaru@uol.com.br
Endodontic irrigation aims to clean and disinfect the root canal system. Passive ultrasonic irrigation (PUI) is based on the use of an ultrasound-activated instrument into the root canal filled with irrigant. The aim of this study was to evaluate, ex vivo, the effectiveness of PUI in eliminating Enterococcus faecalis from root canals. Seventy-five extracted human single-root teeth were used. After root canal preparation, specimens were inoculated with $E$. faecalis and incubated at $37{ }^{\circ} \mathrm{C}$ for 21 days. Specimens were distributed into five groups $(n=15)$, according to the irrigation method: PUI + saline solution (PUI/SS); $\mathrm{PUI}+1 \% \mathrm{NaOCl}(\mathrm{PUI} / \mathrm{NaOCl})$; conventional needle irrigation $(\mathrm{CNI})+$ saline solution (CNI/SS); $\mathrm{CNI}+1 \% \mathrm{NaOCl}(\mathrm{CNI} / \mathrm{NaOCl}) ;$ No irrigation (control). Microbiological samples were collected at three time points: initial ( 21 days after inoculation), post-irrigation (immediately after irrigation), and final (7 days after irrigation). Data were obtained in CFU mL $\mathrm{m}^{-1}$ and subjected to analysis by ANOVA and Tukey's tests at $5 \%$ significance level. The post-irrigation samples did not demonstrate statistical difference between PUI/SS and $\mathrm{CNI} / \mathrm{SS}$ nor between $\mathrm{PUI} / \mathrm{NaOCl}$ and $\mathrm{CNI} / \mathrm{NaOCl}(\mathrm{p}>0.05)$, but $\mathrm{PUI} / \mathrm{NaOCl}$ and $\mathrm{CNI} /$ $\mathrm{NaOCl}$ had lower $\mathrm{CFU} \mathrm{mL} \mathrm{m}^{-1}$ number than the other groups $(\mathrm{p}>0.05)$. Statistically significant difference was observed between the initial and post-irrigation samples and between the post-irrigation and final samples $(p<0.05)$ in all groups, except in the control. The final samples of all groups presented bacterial counts similar to the initial samples. PUI or $\mathrm{CNI}$ with $1 \% \mathrm{NaOCl}$ contribute to disinfection, but are unable to eradicate $E$. faecalis from the root canal system.
Key Words: endodontics, Enterococcus faecalis, passive ultrasonic irrigation, root canal disinfection.

\section{Introduction}

Microorganisms and their products play an essential role in the development of pulp and periapical diseases, and are responsible for endodontic treatment failure (1-3). Biomechanical preparation using antimicrobial irrigants aims to eliminate infection from the root canal system (RCS) $(4,5)$. However, the root canal system anatomy favors the maintenance of infection in the isthmuses, lateral and apical ramifications and flattened areas (6).

The ideal irrigation solution needs to remove debris, lubricate the root canal walls, dissolve organic tissue and eliminate bacteria. Regardless of irrigation solution used, the endodontic microorganisms are reduced by the mechanical action of the irrigation. (7). Sodium hypochlorite $(\mathrm{NaOCl})$ is the most widely used chemical irrigant in Endodontics, due to its antimicrobial properties $(4,8,9)$ and its ability to dissolve organic tissues $(5,10,11)$.

Enterococcus faecalis is the most frequently observed microorganism in persistent infections associated with endodontic failure (12), and has demonstrated the ability to invade the dentine tubules (13). Due to its great resistance, ability to organize into a biofilm and to form a monospecies infection, this microorganism has been extensively used in studies evaluating the effectiveness of irrigating solutions and intracanal medicaments $(1,5,8,12,14)$.

Several irrigation methods have been proposed to enhance the effectiveness of $\mathrm{NaOCl}$ in cleaning and disinfecting the RCS and then in eliminating the microorganisms $(8,15,16)$. Ultrasound has been used in Endodontics to complement the cleaning ability of root canal irrigants. Passive ultrasonic irrigation (PUI) was first described by Weller et al. (17). PUI is based on the use of an ultrasound-activated instrument into the root canal filled with irrigant, inducing acoustic microstreaming in the solution around the tip $(18,19)$.

Studies have demonstrated that $\mathrm{NaOCl}$ solution, in conjunction with PUI in the final step of irrigation, is able to remove more debris, bacteria and pulp tissue compared with conventional irrigation with a needle and syringe $(10,15,16,20)$. However, E. faecalis is a very resistant bacteria and can remain viable within the root canal system. Therefore, it is necessary to evaluate the effect of PUI used immediately after root canal preparation, but also the effect on root canal system.

The aim of this study was to evaluate the effect of PUI compared with conventional needle irrigation (CNI) using 
$1 \% \mathrm{NaOCl}$ or saline solution in eliminating $E$. faecalis. The null hypothesis is that the irrigation methods and irrigating solutions do not influence the elimination of $E$. faecalis from the RCS.

\section{Material and Methods}

\section{Preparation of Root Canals and Tooth Surface}

This study was approved by Ethics Committee of Araraquara Dental School, UNESP, Brazil. Seventy-five human single-rooted teeth with a single straight root canal were used. The crowns were removed and roots were standardized at $15 \mathrm{~mm}$ of length. A size \#3 Gates Glidden drill (Dentsply-Maillefer, Ballaigues, Switzerland) was used on the coronal $3 \mathrm{~mm}$ of the root canal and foramen size was standardized with a size $20 \mathrm{~K}$-file (Dentsply-Maillefer). The working length (WL) was established $1 \mathrm{~mm}$ short of the apical foramen and the root canal was instrumented up to a size $50 \mathrm{~K}$-file (apical stop). After that, the root canals were instrumented by a step-back technique up to a size 70 $\mathrm{K}$-file. Conventional needle irrigation (CNI) was used with $2 \mathrm{~mL}$ saline solution after each file. Subsequently, the root canals were filled with 17\% trisodium EDTA (Biodinâmica, Ibiporã, PR, Brazil) for $3 \mathrm{~min}$, followed by irrigation with 5 $\mathrm{mL}$ of saline solution. Following that, the root apices were sealed with light-cured composite resin (Z250 Universal Restorative; 3M ESPE, St. Paul, MN, USA) and all external root surfaces (except the root canal access) were made impermeable with two layers of epoxy adhesive (Araldite; Brascola Ltda., São Paulo, SP, Brazil), according to ArandaGarcia et al. (21).

Specimens were randomly divided into five 24-well cell culture microplates (Corning Incorporated, Corning, NY, USA). Each microplate received 15 specimens, which were attached to the wells with self-curing acrylic resin (Clássico Artigos Odontológicos, São Paulo, SP, Brazil). The microplates containing the specimens were wrapped and sterilized by ethylene oxide (Acecil, Campinas, SP, Brazil).

\section{Contamination of the Root Canals}

These procedures were carried out in a laminar flow chamber (VecoFlow Ltda., Campinas, SP, Brazil). Standardized E. faecalis strains (ATCC 29212) were cultured in Tryptic Soy Broth - TSB (Difco, Detroit, MI, USA) for $24 \mathrm{~h}$. Bacteria were seeded onto Tryptic Soy Agar - TSA medium (Difco) and incubated at $37^{\circ} \mathrm{C}$ for $48 \mathrm{~h}$. A bacterial suspension was prepared in sterile saline solution, at a concentration equivalent to 0.5 in the McFarland standard. The optical density of the suspension was adjusted using a spectrophotometer (Model 600 Plus; Femto, São Paulo, SP, Brazil) to a concentration equivalent to $1.6 \times 10^{7} \mathrm{CFU} \mathrm{mL}^{-1}$.

Sterile TSB was mixed to the bacterial suspension at a 1:1 ratio, and root canals were contaminated with 20 $\mu \mathrm{L}$ of this mixture. A sterile cotton pellet moistened with TSB was placed at each root canal entrance. Microplates were covered and kept in a microaerophilic environment at $37^{\circ} \mathrm{C}$. During the 21 -day incubation period, sterile TSB was added to each root canal on alternate days by means of a $0.5 \mathrm{~mL}$ insulin syringe (Bectron Dickinson, Curitiba, PR, Brazil), as previously described by Aranda-Garcia et al. (21).

After that, initial samples were collected, in order to confirm contamination by $E$. faecalis. Two \#50 sterile paper points (Tanari Industrial Ltda., São Paulo, SP, Brazil) were used in sequence in each root canal. The paper points remained in the root canal for $1 \mathrm{~min}$ and were subsequently transferred to tubes containing $1 \mathrm{~mL}$ sterile saline solution, which were shaken for 1 min (Vortex AP 56; Phoenix, Araraquara, SP, Brazil). Ten-fold serial dilutions were made and $20 \mu \mathrm{L}$ aliquots were seeded in triplicate onto Petri dishes containing TSA. Following that, the plates were incubated in microaerophilic environment at $37^{\circ} \mathrm{C}$ for 48 h. Bacterial growth was determined by the $\mathrm{CFU} \mathrm{mL}{ }^{-1}$ counts of $E$. faecalis. The microplates containing the roots were randomly distributed in five groups $(n=15)$ according to the irrigation method: PUI + saline solution (PUI/SS); PUI + $1 \% \mathrm{NaOCl}(\mathrm{PUI} / \mathrm{NaOCI}) ; \mathrm{CNI}+$ saline solution (CNI/SS); $\mathrm{CNI}$ $+1 \% \mathrm{NaOCl}(\mathrm{CNI} / \mathrm{NaOCl}$ ); No irrigation (control). (Table 1).

\section{Irrigation Protocols}

Root canals in the groups (except for the control) were irrigated by using a 27-G irrigation needle (Endo-Eze Irrigator; Ultradent Products, South Jordan, UT, USA) and a $5 \mathrm{~mL}$ syringe (Ultradent Products). A rubber stop was placed $14 \mathrm{~mm}$ from the needle tip. All specimens were irrigated for $2 \mathrm{~min}$. For specimens in Groups PUI/saline and $\mathrm{CNI} /$ saline, the irrigant used was $5 \mathrm{~mL}$ of sterile saline solution (Fresenius Kabi Brazil Ltda., Aquiraz, CE, Brazil), while Groups $\mathrm{PUI} / \mathrm{NaOCl}$ and $\mathrm{CNI} / \mathrm{NaOCl}$ were irrigated with $5 \mathrm{~mL}$ of $1 \% \mathrm{NaOCl}$.

In Groups PUI/saline and PUI/NaOCl, a size 25 IRRI S file (VDW; Endo Ultrasonic Files, Endodontic Synergy, Munich, Germany) was inserted until $1 \mathrm{~mm}$ short of the WL. The file

Table 1. Experimental groups and control

\begin{tabular}{llll}
\hline Final irrigation protocol & Total irrigation time & Total volume & $\mathrm{n}$ \\
\hline $\mathrm{PUl}+$ saline & $2 \mathrm{~min}$ & $5 \mathrm{~mL}$ & 15 \\
$\mathrm{PUl}+1 \% \mathrm{NaOCl}$ & $2 \mathrm{~min}$ & $5 \mathrm{~mL}$ & 15 \\
$\mathrm{CNl}+$ saline & $2 \mathrm{~min}$ & $5 \mathrm{~mL}$ & 15 \\
$\mathrm{CNl}+1 \% \mathrm{NaOCl}$ & $2 \mathrm{~min}$ & $5 \mathrm{~mL}$ & 15 \\
Control (no irrigation) & - & - & 15 \\
\hline
\end{tabular}

PUI: passive ultrasonic irrigation; $\mathrm{CNl}$ : conventional needle irrigation. 
was attached to a piezoelectric ultrasonic device operating at $30 \mathrm{kHz}$ (CVDent 1000; CVD Vale, São José dos Campos, $\mathrm{SP}, \mathrm{Brazil})$ set at power level 4. The irrigation protocol was conducted as follows: $2 \mathrm{~mL}$ of irrigant solution using $\mathrm{CNI}$ in the first $30 \mathrm{~s}, 20 \mathrm{~s}$ using PUI, $1 \mathrm{~mL}$ by CNI for $20 \mathrm{~s}, 20$ $\mathrm{s}$ of PUI, followed by $2 \mathrm{~mL}$ of irrigant by using CNI for 30 $\mathrm{s}$, totaling 2 min of irrigation, as previously described by Chávez-Andrade et al. (22).

Specimens in Groups $\mathrm{CNI} /$ saline and $\mathrm{CNI} / \mathrm{NaOCl}$ were submitted to $\mathrm{CNI}$, by applying finger pressure to the plunger of the previously described syringe/needle set. Half of the total irrigant volume was dispensed in the first minute. The solution was agitated in the root canal with a size 50 $\mathrm{K}$-file for $20 \mathrm{~s}$, followed by $40 \mathrm{~s}$ of final irrigation, Half of the total volume of irrigating solution $(2.5 \mathrm{~mL})$ was used in the first minute, followed by agitation in the root canal using a size $50 \mathrm{~K}$-file for $20 \mathrm{sec}$. At the end, $2.5 \mathrm{~mL}$ of solution was used for final irrigation for 40 seconds, totalizing $2 \mathrm{~min}$.

\section{Microbiological Analysis}

Immediately after irrigation, root canals in Groups $\mathrm{PUI} / \mathrm{NaOCl}$ and $\mathrm{CNI} / \mathrm{NaOCl}$ were filled with $1 \%$ sodium thiosulfate in order to neutralize the $\mathrm{NaOCI}(2,8)$. The other groups were filled with saline. Following that, a second microbiological sample was collected from each canal. Two \#50 sterile paper points were used per specimen, as described for the initial sample. After that, root canals were filled with sterile saline solution and sterile cotton pellets were placed at each canal entrance. The microplates containing the specimens were covered and incubated in a microaerophilic environment at $37^{\circ} \mathrm{C}$. After 7 days, the final samples were collected according to the previously

Table 2. Comparison between the groups at the initial, post-irrigation, and final samples (mean and standard deviation of CFU mL-1 log)

\begin{tabular}{lccc}
\hline $\begin{array}{l}\text { Final irrigation } \\
\text { protocol }\end{array}$ & Initial & Post-irrigation & Final \\
\hline $\mathrm{PU1}+$ saline & $7.18( \pm 0.34)^{\mathrm{A}, \mathrm{a}}$ & $5.02( \pm 0.38)^{\mathrm{C}, \mathrm{b}}$ & $6.90( \pm 0.46)^{\mathrm{A}, \mathrm{a}}$ \\
$\mathrm{PU1}+1 \%$ & $6.97( \pm 0.29)^{\mathrm{A}, \mathrm{a}}$ & $1.41( \pm 1.07)^{\mathrm{D}, \mathrm{b}}$ & $6.89( \pm 0.46)^{\mathrm{A}, \mathrm{a}}$ \\
$\mathrm{NaOCl}$ & & & \\
$\mathrm{CN1}+$ saline & $6.96( \pm 0.64)^{\mathrm{A}, \mathrm{a}}$ & $5.18( \pm 0.41)^{\mathrm{CB}, \mathrm{b}}$ & $6.89( \pm 0.58)^{\mathrm{A}, \mathrm{a}}$ \\
$\mathrm{CN1}+1 \%$ & & \\
$\mathrm{NaOCl}$ & $7.15( \pm 0.36)^{\mathrm{A}, \mathrm{a}}$ & $0.89( \pm 1.14)^{\mathrm{D}, \mathrm{b}}$ & $7.16( \pm 0.11)^{\mathrm{A}, \mathrm{a}}$ \\
$\begin{array}{l}\text { Control }(\mathrm{no} \\
\text { irrigation }\end{array}$ & $6.84( \pm 0.41)^{\mathrm{A}, \mathrm{a}}$ & $6.64( \pm 0.54)^{\mathrm{AB}, \mathrm{a}}$ & $6.82( \pm 0.13)^{\mathrm{A}, \mathrm{a}}$ \\
\hline
\end{tabular}

Different letters indicate statistically significant difference $(\mathrm{p}<0.05)$. Uppercase letters for comparison between groups and lower-case letters for comparison between samples. PUI: passive ultrasonic irrigation; $\mathrm{CNI}$ : conventional needle irrigation. described steps, in order to recover microorganisms that had remained in the dentine tubules and root canal system. Data obtained were submitted to base-10 logarithmic transformation and analyzed by the GraphPad Prism 3.0 software (San Diego, CA, USA). ANOVA and Tukey's tests were used for comparison among the groups. For comparison between samples within the same group, repeated measures ANOVA test was used. The significance level was set at $p<0.05$.

\section{Results}

Contamination of the specimens with the standard $E$. faecalisstrain was confirmed in the initial samples, collected after 21 days of incubation. All groups had similar CFU $\mathrm{mL}^{-1}$ counts, as shown in Table 2. Viability of $E$. faecalis in the control group, which was not submitted to irrigation, was confirmed throughout the entire experimental period. Comparison between the post-irrigation samples from each group did not show statistically significant difference between $\mathrm{PUI} /$ saline and $\mathrm{CNI} /$ saline nor between $\mathrm{PUI} / \mathrm{NaOCl}$ and $\mathrm{CNI} / \mathrm{NaOCl}(\mathrm{p}>0.05)$. However, immediately after irrigation $\mathrm{PUI} \mathrm{NaOCl}$ and $\mathrm{CNI} / \mathrm{NaOCl}$ had lower $\mathrm{CFU} \mathrm{mL}^{-1}$ counts than the other two groups ( $p>0.05$ ). Significant difference was observed between the control group and all other groups, except for $\mathrm{CNI} /$ saline. In the final samples, all groups showed similar results with no statistical difference. As shown in Table 2, comparison between samples within each group demonstrated statistically significant difference between the initial and the post-irrigation samples, as well as between the post-irrigation and the final samples $(p<0.05)$ in all groups, except for the control.

\section{Discussion}

Several studies use $E$. faecalis to evaluate the antimicrobial effect of different medicaments, irrigants and treatment protocols $(8,14,23,24)$. The methodology used in this study simulates the clinical infection in the RCS, using an E. faecalis 21-day incubation period, as described in previous study (21). The use of sterile paper points for sample collection allows recovery of bacteria present only in the root canal lumen. The final samples, collected 7 days after irrigation, showed permanence of viable bacteria within the RCS. E. faecalis has demonstrated resistance to several antibacterial agents $(8,14)$. This microorganism invades the dentin tubules and is able to survive in the RCS, even after root canal treatment $(12,13)$. Moreover, $E$. faecalis can be used in experiments after isolation and conventional culture methods $(8,23)$.

The methodology used in this study allows standardization of samples. This was confirmed 
by the homogeneity of the initial samples, 21 days after inoculation. Analysis of the different irrigation protocols revealed that $1 \% \mathrm{NaOCl}$ was the most effective irrigant against $E$. faecalis, regardless of the irrigation method (CNI or PUI). However, seven days after irrigation, increase in the bacterial counts was observed in all groups, demonstrating permanence of $E$. faecalis in the RCS. These results are in agreement with those of previous studies $(1,23,24)$ that did not observe significant difference between $\mathrm{CNI}$ and $\mathrm{PUI}$ when $\mathrm{NaOCl}$ was used as irrigant.

The $1 \% \mathrm{NaOCl}$ was used in this study to evaluate the effect of PUl using a low sodium hypochlorite concentration. Previous studies $(1,14)$ using this concentration observed antibacterial effect using the association of $1 \% \mathrm{NaOCl}$ and PUI immediately after irrigation. However, Tardivo et al. (23) observed that 5.25\% and PUI did not increase antibacterial effect against $E$. faecalis, in comparison with manual irrigation using this solution.

$\mathrm{PUI}$ has been suggested as an alternative to $\mathrm{CNI}$ to more effectively clean and disinfect the $\operatorname{RCS}(10,17,18)$. The present study evaluated the effect of PUI in an infected root canal system model. The results from the present study did not show significant difference after irrigation by using PUI. The irrigating solution was essential, with better results with the use of $\mathrm{NaOCl}$. The final samples showed no differences between the groups, including specimens irrigated using $\mathrm{NaOCl}$ with or without ultrasonic activation. Gründling et al. (24) also evaluated PUI and CNI using 2\% $\mathrm{NaOCl}$ in conjunction with 17\% EDTA and distilled water, and did not find significant differences between these irrigation protocols.

Some studies report different outcomes regarding the antimicrobial efficacy of PUI. These differences may be related to the use of bacterial strains more susceptible to disinfection procedures (25) as well as to shorter incubation periods, or still to microbiological analysis being only performed immediately after treatment (1). Cohenca et al. (15) showed better root canal disinfection using PUI associated with $2.5 \% \mathrm{NaOCl}$ than $\mathrm{CNI}$ in root canals of dog's teeth with apical periodontitis.

Other methodologies, such as the one described by Harrison et al. (14) involving scanning electron microscopy (SEM) specimen analysis, showed that irrigation with $1 \% \mathrm{NaOCl}$ for $1 \mathrm{~min}$ after biomechanical preparation is effective to promote reduction of $E$. faecalis within the root canals. Bhuva et al. (1) also performed SEM to evaluate the effectiveness of PUI with $1 \% \mathrm{NaOCl}$ for removal of $E$. faecalis biofilm and concluded that this treatment was able to completely remove intracanal biofilm. However, these authors did not observe significant difference between PUI and $\mathrm{CNI}$, which is in agreement with the results obtained in the present study.
In conclusion, both PUI and $\mathrm{CNI}$ with $1 \% \mathrm{NaOCl}$ contribute for disinfection, but are unable to eliminate E. faecalis from the root canal system. The present results suggest that the use of an irrigating solution with antimicrobial activity plays an essential role in root canal disinfection.

\section{Resumo}

A irrigação endodôntica visa à limpeza e desinfecção do sistema de canais radiculares. A irrigação ultrassônica passiva (IUP) baseia-se na utilização de um instrumento ultrassônico ativado no interior do canal radicular preenchido com a solução irrigadora. 0 objetivo deste estudo foi avaliar, ex vivo, a eficácia da IUP na eliminação de Enterococcus faecalis dos canais radiculares. Foram usados 75 dentes humanos unirradiculares extraidos. Após o preparo biomecânico dos canais radiculares, foram inoculados com $E$. faecalis e incubados a $37^{\circ} \mathrm{C}$ por 21 dias. Os espécimes foram distribuídos em cinco grupos $(n=15)$, de acordo com o método de irrigação: IUP + solução salina (IUP/SS); IUP + $\mathrm{NaOCl}$ a 1\% (IUP/ $\mathrm{NaOCI})$; irrigação manual convencional (IMC) + solução salina (IMC/ sol); IMC + $\mathrm{NaOCl}$ a $1 \%(\mathrm{IMC} / \mathrm{NaOCI}) ;$ Sem irrigação (controle). Foram realizadas três coletas microbiológicas: inicial (21 dias após a inoculação), pós-irrigação (imediatamente após a irrigação), e final (7 dias após a irrigação). Os dados foram obtidos em UFC $\mathrm{mL}^{-1}$ e submetidos aos testes de ANOVA e Tukey. A coleta pós-irrigação não demonstrou diferença estatisticamente significante entre IUP/SS e IMC/SS nem entre IUP/ $\mathrm{NaOCl}$ e IMC/NaOCl $(p>0,05)$, mas IUP/ $\mathrm{NaOCl}$ e IMC/NaOCl apresentaram menor número de UFC $\mathrm{mL}^{-1}$ comparado aos outros grupos $(\mathrm{p}>0,05)$. Diferença estatisticamente significante foi observada entre as coletas iniciais e pós-irrigação e entre a pós-irrigação e a coleta final $(p<0,05)$ em todos os grupos, exceto no controle. Na coleta final, todos os grupos apresentaram contagem bacteriana similar à coleta inicial. IUP ou IMC com $\mathrm{NaOCl}$ a $1 \%$ contribuem para a desinfecção, mas não eliminam $E$. faecalis do sistema de canais radiculares.

\section{References}

1. Bhuva $B$, Patel $S$, Wilson $R$, Niazi S, Beighton D, Mannocci F. The effectiveness of passive ultrasonic irrigation on intraradicular Enterococcus faecalis biofilms in extracted single-rooted human teeth. Int Endod J 2010;43:241-250.

2. Guerreiro-Tanomaru JM, Morgental RD, Faria-Junior NB, Berbert FL, Tanomaru-Filho M. Antibacterial effectiveness of peracetic acid and conventional endodontic irrigants. Braz Dent J 2011;22:285-287.

3. Vivan RR, Bortolo MV, Duarte MA, Moraes IG, Tanomaru-Filho M, Bramante CM. Scanning electron microscopy analysis of RinsEndo system and conventional irrigation for debris removal. Braz Dent J 2010;21:305-309.

4. Pereira ES, Peixoto IF, Nakagawa RK, Buono VT, Bahia MG. Cleaning the apical third of curved canals after different irrigation protocols. Braz Dent J 2012;23:351-356.

5. Poggio C, Colombo M, Scribante A, Sforza D, Bianchi S. In vitro antibacterial activity of different endodontic irrigants. Dent Traumatol 2012;28:205-209.

6. Lorencetti KT, Silva-Sousa YT, Nascimento GE, Messias DC, Colucci $V$, Rached-Junior FA, et al.. Influence of apical enlargement in cleaning of curved canals using negative pressure system. Braz Dent J 2014;25:430-434.

7. Guerreiro-Tanomaru JM, Loiola LE, Morgental RD, Leonardo R de T, Tanomaru-Filho M. Efficacy of four irrigation needles in cleaning the apical third of root canals. Braz Dent J 2013;24:21-24.

8. Estrela C, Sousa-Neto MD, Alves DR, Alencar AH, Santos TO, Pecora JD. A preliminary study of the antibacterial potential of cetylpyridinium chloride in root canals infected by E. faecalis. Braz Dent J 2012;23:645653.

9. Zehnder M. Root canal irrigants. J Endod 2006;32:389-398.

10. Al-Jadaa A, Paque F, Attin T, Zehnder M. Necrotic pulp tissue dissolution 
by passive ultrasonic irrigation in simulated accessory canals: impact of canal location and angulation. Int Endod J 2009;42:59-65.

11. Estrela C, Estrela CR, Barbin EL, Spano JC, Marchesan MA, Pecora JD. Mechanism of action of sodium hypochlorite. Braz Dent J 2002;13:113117.

12. Tennert C, Fuhrmann M, Wittmer A, Karygianni L, Altenburger MJ, Pelz $\mathrm{K}$, et al.. New bacterial composition in primary and persistent/ secondary endodontic infections with respect to clinical and radiographic findings. J Endod 2014;40:670-677.

13. Chivatxaranukul P, Dashper SG, Messer HH. Dentinal tubule invasion and adherence by Enterococcus faecalis. Int Endod J 2008;41:873-882.

14. Harrison AJ, Chivatxaranukul $P$, Parashos $P$, Messer HH. The effect of ultrasonically activated irrigation on reduction of Enterococcus faecalis in experimentally infected root canals. Int Endod J 2010;43:968-977.

15. Cohenca N, Silva LA, Silva RA, Nelson-Filho P, Heilborn C, Watanabe E, et al.. Microbiological evaluation of different irrigation protocols on root canal disinfection in teeth with apical periodontitis: an in vivo study. Braz Dent J 2013;24:467-473.

16. Rodig T, Sedghi M, Konietschke F, Lange K, Ziebolz D, Hulsmann M. Efficacy of syringe irrigation, RinsEndo and passive ultrasonic irrigation in removing debris from irregularities in root canals with different apical sizes. Int Endod J 2010;43:581-589.

17. Weller RN, Brady JM, Bernier WE. Efficacy of ultrasonic cleaning. J Endod 1980;6:740-743.

18. van der Sluis LW, Versluis M, Wu MK, Wesselink PR. Passive ultrasonic irrigation of the root canal: a review of the literature. Int Endod J 2007;40:415-426.
19. Jiang LM, Verhaagen $B$, Versluis $M$, Langedijk J, Wesselink $P$, van der Sluis LW. The influence of the ultrasonic intensity on the cleaning efficacy of passive ultrasonic irrigation. J Endod 2011;37:688-692.

20. Nadalin MR, Perez DE, Vansan LP, Paschoala C, Souza-Neto MD, Saquy PC. Effectiveness of different final irrigation protocols in removing debris in flattened root canals. Braz Dent J 2009;20:211-214.

21. Aranda-Garcia AR, Guerreiro-Tanomaru JM, Faria-Junior NB, ChavezAndrade GM, Leonardo RT, Tanomaru-Filho M, et al.. Antibacterial effectiveness of several irrigating solutions and the Endox Plus system - an ex vivo study. Int Endod J 2012;45:1091-1096.

22. Chávez-Andrade GM, Guerreiro-Tanomaru JM, Miano LM, Toledo RL, Tanomaru-Filho M. Radiographic evaluation of root canal cleaning, main and laterals, using different methods of final irrigation. Rev Odontol UNESP 2014;43:333-337.

23. Tardivo D, Pommel L, La Scola B, About I, Camps J. Antibacterial efficiency of passive ultrasonic versus sonic irrigation. Ultrasonic root canal irrigation. Odontostomatol Trop 2010;33:29-35.

24. Grundling GL, Zechin JG, Jardim WM, de Oliveira SD, de Figueiredo JA. Effect of ultrasonics on Enterococcus faecalis biofilm in a bovine tooth model. J Endod 2011;37:1128-1133.

25. Weber CD, McClanahan SB, Miller GA, Diener-West M, Johnson JD. The effect of passive ultrasonic activation of $2 \%$ chlorhexidine or $5.25 \%$ sodium hypochlorite irrigant on residual antimicrobial activity in root canals. J Endod 2003;29:562-564.

Received January 12, 2015 Accepted 17 April, 2015 